\title{
PENGARUH MODEL PEMBELAJARAN CREATIVE PROBLEM SOLVING BERBANTUAN MEDIA BERBASIS TIK TERHADAP KEMAMPUAN BERPIKIR KREATIF DALAM MEMECAHKAN MASALAH MATEMATIKA SISWA KELAS VIII SMPN 1 BANGLI
}

\author{
N. P. Yuliastuti, I. N. Sukajaya, N. M. S. Mertasari \\ Jurusan Pendidikan Matematika \\ Universitas Pendidikan Ganesha \\ Singaraja, Indonesia \\ e-mail: \{ni.putu.yuliastuti, nyoman sukajaya, srimertasari\}@undiksha.ac.id
}

\begin{abstract}
Abstrak
Penelitian ini bertujuan untuk mengetahui pengaruh model pembelajaran creative problem solving berbantuan media berbasis TIK terhadap kemampuan berpikir kreatif dalam memecahkan masalah matematika siswa. Jenis penelitian ini adalah eksperimen semu dengan desain penelitian adalah Post Test Only Control Group. Populasi penelitian ini adalah seluruh siswa kelas VIII SMPN 1 Bangli tahun ajaran 2018/2019. Sampel dalam penelitian ini adalah siswa kelas VIII A dan VIII E yang diambil menggunakkan teknik cluster random sampling. Data dikumpulkan dengan tes kemampuan berpikir kreatif yang diberikan kepada siswa dalam bentuk tes uraian dan diberikan di akhir penelitian. Data hasil tes kemampuan berpikir kreatif dianalisis menggunakan uji$t$ satu ekor dengan taraf siginifikansi 5\%. Hasil penelitian menunjukkan bahwa $t_{\text {hitung }}=0,206>t_{\text {tabel }}=0,063$ sehingga $H_{0}$ ditolak. Ini berarti, kemampuan berpikir kreatif dalam memecahkan masalah matematika siswa yang dibelajarkan dengan model pembelajaran creative problem solving berbantuan media berbasis TIK lebih baik daripada kemampuan berpikir kreatif dalam memecahkan masalah matematika siswa yang dibelajarkan dengan model pembelajaran konvensional. Dengan demikian, dapat disimpulkan bahwa terdapat pengaruh model pembelajaran creative problem solving berbantuan media berbasis TIK terhadap kemampuan berpikir kreatif dalam memecahkan masalah matematika siswa.
\end{abstract}

Kata kunci: model pembelajaran creative problem solving, media berbasis TIK, berpikir kreatif

Abstract

This study aims to determine the effect of creative problem soving learning model supported by ICT-based media to student's creative thinking abilities in mathematical problem solving. Quasi-experiment was used in this study with posttest only control group design. The population of this study was all students of class VIII SMPN 1 Bangli in the academic year 2018/2019. VIII A and VIII E classes were selected to be the sample of this study by using cluster random sampling technique. Data were collected through test of creativity thinking abilities given to in the form of essay test and given at the end of study. Data from the test results of creativity thinking ability were analyzed using one-tailed t-test with a significance level of 5\%. The result showed $t_{\text {hitung }}=0,206>t_{\text {tabel }}=0,063$ that the $H_{0}$ was rejected. This means that the creative thinking abilities in mathematical problem solving who are taught by creative problem soving learning model supported by ICT-based media are better than students' mathematical problem solving abilities taught by conventional learning model, so it can be conclude that there is an effect of creative problem soving learning model supported by ICT-based media to students' creative thinking abilities in mathematical problem solving.

Keywords: creative problem soving learning model, ICT-based media, creative thinking.

\section{PENDAHULUAN}

Hasil survey internasional TIMSS (Trend in International Mathematic and Science Study) 2011 di bidang matematika untuk peserta didik kelas VIII SMP, Indonesia berada di peringkat ke-38 dari 42 negara dengan skor rata-rata 386, sedangkan skor rata-rata internasional 500. Hasil studi TIMSS tersebut menunjukkan kurangnya kemampuan siswa dalam memecahkan masalah yang non-rutin dan hanya dapat menyelesaikan masalah rutin atau masalah sederhana saja. Hal ini menunjukkan kurangnya kemampuan siswa dalam berpikir matematika tingkat tinggi salah satunya berpikir kreatif. Selain itu, dinyatakan bahwa 
hanya $2 \%$ siswa Indonesia yang dapat mengerjakan soal-soal kategori high dan advance yang membutuhkan kemampuan berpikir kreatif dalam menyelesaikannya (Mullis, dkk., 2012).

Pernyataan tersebut didukung juga oleh hasil penelitian Lisliana, Agung Hartoyo dan Bistari (2016) yang menyatakan bahwa sebagian besar siswa SMP memiliki kemampuan berpikir kreatif yang masih kurang bahkan tidak memiliki kemampuan berpikir kreatif dalam menyelesaikan masalah matematika. Pernyataan tersebut menunjukkan bahwa sebagian besar siswa belum memiliki kemampuan berpikir kreatif yang baik. Kemampuan berpikir kreatif siswa harusnya dapat digunakan sebagai petunjuk untuk mengetahui kualitas kemampuan siswa dalam berpikir kreatif dan perkembangannya selama proses pembelajaran (Susanto, 2011).

Kemampuan berpikir kreatif adalah kemampuan menyampaikan berbagai gagasan dari sebuah masalah yang merupakan salah satu tuntutan dasar yang harus dimiliki oleh siswa. Berpikir kreatif berawal dari kepekaan terhadap suatu masalah. Munandar (1999) mengungkapkan bahwa kemampuan berpikir kreatif memiliki empat indikator yaitu (1) kelancaran yaitu kemampuan memberikan berbagai respon, ide, atau solusi alternatif, (2) fleksibilitas yaitu kemampuan untuk melihat suatu masalah dari sudut pandang yang berbeda-beda, (3) keaslian yaitu kemampuan siswadalam menghasilkan strategi menjawab yang tidak biasa (belum diajarkan), (4) elaborasi yaitu kemampuan untuk menguraikan sesuatu secara lebih terperinci. Jika siswa mampu menguasai minimal tiga indikator yaitu kelancaran, fleksibilitas dan keaslian, maka dapat dikatakan bahwa siswa tersebut kreatif.

Kemampuan berpikir kreatif sangat diperlukan dalam memecahkan masalah matematika. Pada umumnya masalah matematika diberikan dalam bentuk soal cerita, sehingga tidak hanya menggunakan satu cara untuk dapat menemukan solusi dari pemecahan masalah matematika yang disajikan. Diperlukan berbagai gagasan atau ide-ide dari siswa untuk dapat menyelesaikan masalah matematika dengan berbagai macam solusi. Selain memerlukan lebih dari satu cara dan berbagai gagasan siswa, perlu juga adanya ideide baru untuk memecahkan masalah yang diberikan.

Berdasarkan uraian di atas, salah satu upaya yang dapat dilakukan yaitu dengan memaksimalkan atau melakukan inovasi terkait model pembelajaran yang diterapkan. Sehubungan dengan hal tersebut, maka salah satu alternatif model pembelajaran yang dapat diterapkan yaitu model pembelajaran Creative Problem Solving (CPS). Model pembelajaran CPS adalah salah satu model pembelajaran yang berbasis masalah. Pemecahan masalah dalam model ini menggunakan teknik sistematik dalam mengorganisasikan gagasan kreatif dari siswa. Ketika siswa dihadapkan dengan suatu pertanyaan yang berupa permasalahan, siswa dapat memecahkan masalah dari pertanyaan tersebut dengan berbagai solusi. Dengan demikian, siswa tidak hanya menghafal tanpa berpikir tetapi siswa juga dapat memperluas proses berpikir mereka.

Nopitasari (dalam Isrok'atun \& Amelia Rosmala, 2018) mengemukakan bahwa model pembelajaran CPS adalah salah satu model pemecahan masalah yang menekankan penemuan berbagai alternatif ide atau gagasan untuk menentukan penyelesaian berupa solusi yang paling efisien dari suatu permasalahan menggunakan proses berpikir divergen dan konvergen. Hal ini sejalan dengan pendapat dari Kirton (dalam Isrok'atun \& Amelia Rosmala, 2018) bahwa "Creative Problem Solving (CPS) is the association between problem solving and creative thinking". Sehingga dapat dikatakan bahwa model pembelajaran CPS adalah model pembelajaran yang menekankan pada pemecahan masalah dan berpikir kreatif dengan proses berpikir divergen dan konvergen.

Keefektifan penerapan model pembelajaran CPS dalam pembelajaran matematika di kelas telah dibuktikan melalui beberapa penelitian. Penelitian yang dilakukan oleh Yudi Karsana (2016) menunjukkan bahwa terdapat perbedaan kemampuan berpikir kritis matematis siswa yang mendapat pembelajaran dengan model pembelajaran CPS dengan pembangkit rasa jengah dengan siswa yang mendapat pembelajaran konvensional. 
Penelitian lainnya dilakukan oleh Bagus Pramartha (2015) menunjukkan bahwa kelompok siswa yang mendapatkan perlakuan berupa pembelajaran model CPS dengan berbantuan alat peraga geometris memiliki kemampuan operasi bentuk aljabar yang lebih baik dibandingkan dengan kelompok siswa dengan pembelajaran konvensional.

Selain menerapkan model pembelajaran CPS, untuk meningkatkan keefektifan pembelajaran dan mengoptimalkan penerapan model pembelajaran CPS, sehingga dapat membantu peningkatan kemampuan berpikir kreatif siswa, diperlukan bantuan berupa media pembelajaran. Dalam penelitian ini, media pembelajaran yang digunakan adalah media yang telah dikembangkan oleh Desak Nyoman Inten Kencana Dewi serta media yang diunduh dari https://www.geogebra.org. Media pembelajaran sangat berkaitan dengan komponen pembelajaran yang terdiri dari materi pembelajaran, model pembelajaran dan media pembelajaran, evaluasi pembelajaran, serta tujuan pembelajaran. Menurut Briggs (1977) media pembelajaran adalah sarana untuk memberikan rangsangan kepada siswa agar proses belajar dapat berjalan dengan baik. Dalam penelitian ini, media digunakan untuk membantu siswa memahami konsep dari materi yang diberikan. Akibatnya, siswa dapat lebih mudah dalam memecahkan masalah yang diberikan dan objek yang sulit dibayangkan dapat dilihat langsung pada media pembelajaran. Penggunaan media ini diharapkan dapat meningkatkan keterlibatan siswa dalam pembelajaran, sehingga pembelajaran lebih komunikatif dan memungkinkan siswa berinteraksi langsung dengan sumber belajar.

Keterkaitan antara sintaks model pembelajaran CPS yang terdiri dari (1) klarifikasi masalah, (2) pengungkapan pendapat, (3) evaluasi dan pemilihan, dan (4) implementasi yang berbantuan media berbasis TIK dengan indikator kemampuan berpikir kreatif yaitu kelancaran, fleksibilitas, dan keaslian terdapat pada semua sintaks dari model pembelajaran CPS.

Sintaks pertama adalah klarifikasi masalah, yaitu kegiatan menganalisa permasalahan yang diberikan. Dalam kegiatan ini diperlukan pemikiran ide-ide yang relevan terkait pemecahan masalah (kelancaran). Selain itu diperlukan juga pemahaman tentang permasalahan tersebut yang dilihat dari sudut pandang yang berbeda-beda (fleksibilitas). Sehingga pada tahap ini siswa sudah dapat memikirkan penyelesaian masalah yang akan digunakan. Sintaks kedua adalah brainstorming, yaitu penyampaian gagasan-gagasan dari siswa tentang strategi pemecahan masalah. Dalam tahap ini siswa harus memikirkan ide-ide yang relevan (kelancaran), melihat permasalahan dari sudut pandang yang berbeda (fleksibilitas), serta diharapkan siswa mampu menyampaikan strategi pemecahan masalah yang belum pernah diberikan oleh guru (keaslian). Pada sintaks selanjutnya yaitu Evaluasi dan pemilihan, dimana pada tahap ini siswa akan memilih strategi yang paling tepat yang akan digunakan dalam pemecahan masalah. Pada tahap ini juga diharapkan siswa mampu berpikir luwes, fleksibel, serta original. Begitu juga dengan sintaks yang terakhir yaitu implementasi, pada tahap ini siswa menerapkan strategi yang telah dipilih sebagai strategi dari pemecahan masalah yang diberikan. Sehingga ketiga indikator kemampuan berpikir kreatif matematika siswa dapat tercapai. Selama pelaksanaan proses pembelajaran, siswa dibantu dengan media pembelajaran yang telah disediakan. Oleh sebab itu, siswa dapat dengan mudah memahami konsep yang selanjutnya digunakan untuk memecahkan masalah yang diberikan, sehingga dapat membantu meningkatkan kemampuan berpikir kreatif siswa. Jadi dapat disimpulkan bahwa dengan menerapkan model pembelajaran CPS berbantuan media berbasis TIK dapat melatih siswa untuk meningkatkan kemampuan berpikir kreatif dalam memecahkan masalah matematika.

Berdasarkan pemaparan di atas, penulis mencoba untuk melihat pengaruh yang ditimbulkan terhadap kemampuan berpikir kreatif dalam memecahkan masalah matematika siswa yang dibelajarkan dengan model pembelajaran CPS berbantuan media berbasis TIK. 


\section{METODE}

Penelitian ini merupakan penelitian eksperimen semu (quasi experiment), karena tidak seluruh variabelnya diatur dan dikontrol secara ketat. Rancangan penelitian ini menggunakan post test only control group design, artinya pada pertemuan terakhir kedua kelompok tersebut akan diberikan tes yang sama (post-test), selanjutnya skor dari post-test tersebut digunakan sebagai pedoman dalam melakukan uji hipotesis.

Populasi dalam penelitian ini adalah seluruh siswa VIII SMP Negeri 1 Bangli tahun pelajaran 2018/2019 yang terdiri dari 10 kelas. Sampel yang digunakan diperoleh dengan melakukan penarikan sampel yaitu memilih dua kelas dari sepuluh kelas yang ada dengan teknik cluster random sampling yaitu pemilihan sampel yang dilakukan secara acak tanpa memperhatikan strata yang ada dalam populasi tersebut. Setelah terpilih dua kelas, kedua kelas ini akan dilakukan uji kesetaraan dengan uji-t untuk mengetahui homogenitas kedua kelas. Data yang digunakan sebagai dasar pengujian kesetaraan pada penelitian ini adalah nilai ulangan umum dua kelas yang terpilih.

Jika kedua kelas dinyatakan tidak setara maka akan dilakukan pengundian ulang sehingga diperoleh dua kelas yang setara yaitu kelas VIII A dan VIII E. Dua kelas yang terpilih, diundi kembali untuk menentukan kelompok kontrol dan kelompok eksperimen. Berdasarkan hasil pengundian, terpilih kelas VIII A sebagai kelompok eksperimen dan kelas VIII E sebagai kelompok kontrol.

Terdapat dua jenis variabel yang terlibat dalam penelitian ini, yaitu variabel bebas (independent variable) dan variabel terikat (dependent variable). Variabel bebas dalam penelitian ini adalah model pembelajaran, dimana model pembelajaran CPS berbantuan media berbasis TIKditerapkan pada kelas eksperimen dan model pembelajaran konvensional diterapkan pada kelas kontrol.Variabel terikat dalam penelitian ini adalah kemampuan berpikir kreatif dalam memecahkan masalah matematika siswa kelas VIII SMP Negeri 1 Bangli. Rancangan penelitian ini dapat dilihat pada Tabel 1. Instrumen yang digunakan dalam penelitian ini berupa tes kemampuan berpikir kreatif yang berbentuk uraian (essay). Kemampuan berpikir kreatif dalam memecahkan masalah matematika siswa diukur dari kemampuan siswa memberikan lebh dari satu jawaban, membuat lebih dari satu cara dari suatu penyelesaian masalah, dan memberikan cara menjawab yang tidak biasa. Instrumen yang baik harus memenuhi dua persyaratan penting yaitu valid dan reliabel.

Uji coba instrumen penelitian dilakukan untuk mendapatkan gambaran secara empirik apakah instrumen penelitian berupa tes kemampuan berpikir kreatif siswa layak digunakan sebagai instrumen.Sebelum diberikan kepada siswa yang menjadi sampel penelitian, akan dilakukan beberapa uji terhadap instrumen penelitian untuk mendapatkan tes yang baik. Pertama akan dilakukan uji pakar/ahli untuk mengetahui validitas isi instrumen. Validitas isi dilakukan oleh dua orang pakar yang merupakan dosen di Jurusan Matematika Undiksha.

Perhitungan validitas isi dilakukan dengan formula Gregory dan dari hasil perhitungan diperoleh koefisien validitas isi tes kemampuan pemecahan masalah yang akan diujicobakan adalah 1,00 yang berarti tes kemampuan yang akan diujicobakan sangat relevan. Selanjutnya, tes kemampuan berpikir kreatif diuji coba pada kelas VIII A SMP Negeri 3 Susut dengan total soal yang diuji cobakan adalah 8 butir soal dan hasilnya digunakan untuk menghitung validitas dan reliabilitas instrumen tersebut. 


\section{HASIL DAN PEMBAHASAN}

Tabel3. Rangkuman Hasil Uji- $t$

\begin{tabular}{ccc}
\hline \multirow{2}{*}{ Variabel } & \multicolumn{2}{c}{ Post-test } \\
\cline { 2 - 3 }$N$ & KelompokEksperimen & KelompokKontrol \\
\hline$N$ & 32 & 32 \\
$\bar{X}$ & 62 & 62 \\
$S D$ & 24,827 & 24,132 \\
$t_{\text {hitung }}$ & 18,40 & 15,04 \\
$t_{\text {tabel }}$ & & 0,206 \\
\hline
\end{tabular}

Rangkuman analisis terhadap skor kemampuan berpikir kreatif dalam memecahkan masalah matematika siswa pada kelompok eksperimen dan kelompok control dapat dilihat pada Tabel 2. Pengujian normalitas sebaran data pada penelitian ini dilakukan dengan menggunakkan uji Kolmogorov-Smirnov pada taraf signifikan 5\%. Hasil analisis uji normalitas pada kelompok eksperimen dengan data sebanyak 32, menunjukkan bahwa nilai $D_{\text {hitung }}$ sebesar0,166 dan nilai $D_{\text {tabel }}$ sebesar 0,24. Sedangkan, pada kelompok control dengan data sebanyak 32, menunjukkan bahwa $D_{\text {hitung }}$ sebesar 0,207 dan $D_{\text {tabel }}$ sebesar 0,24. Terlihat bahwa pada kelompok eksperimen maupun kelompok kontrol menunjukkan nilai $D_{\text {hitung }}<D_{\text {tabel }}$. Ini berarti, data kemampuan berpikir kreatif siswa berasal dari populasi yang berdistribusi normal. Analisis data dilanjutkan dengan melakukan pengujian homogenitas varians. Pada penelitian ini, pengujian varians dilakukan dengan menggunakkan uji- $F$ dan diperoleh $F_{\text {hitung }}=1,50$. Berdasarkan table untuk taraf signifikan $5 \%$, $d k$ pembilang $=31$ dan $d k$ penyebut $=31$, diperoleh $F_{\text {tabel }}=F_{(0,05),(31,31)}=1,82$. Karena $F_{\text {hitung }}<F_{\text {tabel }}$, ini berarti data kemampuan berpikir kreatif siswa mempunyai varians yang homogen.

Berdasarkan hasil uji normaltas dan homogenitas varians, diperoleh bahwa sebaran data kemampuan berpikir kreatif siswa pada kelompok eksperimen dan kelompok kontrol berdistribusi normal, serta memiliki varians yang homogen. Selanjutnya dilakukan uji hipotesis dengan menggunakkan uji- $t$ satu ekor pada taraf signifikan $5 \%$. Rangkuman hasil analisis uji-t dapat dilihat pada Tabel 3. Berdasarkan Tabel 3, menunjukkan bahwa

Tabel2. RangkumanAnalisisterhadap Data KemampuanBerpikirKreatifSiswa

\begin{tabular}{ccc}
\hline \multirow{2}{*}{ Variabel } & \multicolumn{2}{c}{ Post-test } \\
\cline { 2 - 3 } & KelompokEksperimen & KelompokKontrol \\
\hline $\mathrm{N}$ & 32 & 32 \\
Mean & 24,83 & 24,13 \\
Varians & 338,56 & 226,2016 \\
$S D$ & 18,40 & 15,04 \\
Maximum & 88,89 & 66,67 \\
Minimum & 5,56 & 5,56 \\
\hline
\end{tabular}


$t_{\text {hitung }}>t_{\text {tabel }}$. Ini berarti, kemampuan berpikir kreatif dalam memecahkan masalah matematika siswa yang dibelajarkan dengan model pembelajaran CPS berbantuan media berbasis TIK lebih baik daripada kemampuan berpikir kreatif dalam memecahkan masalah matematika siswa yang dibelajarkan dengan model pembelajaran konvensional.

Terjadinya hal tersebut sebabperbedaan perlakuan antara kelompok eksperimen dan kelompok kontrol. Perlakuan yang dimaksud adalah adanya perbedaan kegiatan pembelajaran yang berlangsung di kelas. Perbedaan tersebut dilihat dari langkah-langkah pembelajaran yang dilaksanakan. Pada kelompok eksperimen langkah pembelajaran CPS berbantuan media berbasis TIK memiliki kontribusi yang besar dalam meningkatkan kemampuan berpikir kreatif siswa.

Pada fase klarifikasi masalah, guru mengarahkan siswa untuk mencermati masalah pada LKS yang telah dibagikan. Siswa sangat antusias dalam mencermatinya karena keaktifan mereka dalam bertanya dan menggali informasi baik melalui media pembelajaran maupun melalui buku pegangan mereka. Melihat antusias siswa tentunya secara tidak langsung mengarahkan mereka untuk menggali informasi dan pengetahuan mereka yang berkaitan dengan masalah yang ada di LKS. Situasi ini memperlihatkan usaha siswa untuk menyelesaikan masalah yang diberikan. Pada tahap ini siswa kebingungan dalam menggunakan media pembelajaran, namun dapat diatasi dengan mendemonstrasikan cara penggunaan media di depan kelas.

Pada fase brainstorming, fase ini disebut juga fase pengungkapan pendapat dimana siswa bebas mengungkapkan pendapatnya terkait strategi pemecahan masalah. Antusias siswa dalam fase ini juga sangat terlihat. Banyak siswa yang berani mengacungkan tangannya untuk menyampaikan pendapat terkait strategi pemecahan masalah yang diberikan. Satu persatu siswa mencoba menyampaikan gagasannya. Meskipun ada beberapa pendapat mereka yang tidak sesuai dengan pemecahan masalah, namun semangat yang diperlihatkan siswa membuat guru lebih mudah untuk mengarahkan siswa dalam memutuskan strategi mana yang akan dipilih sebagai strategi pemecahan masalah yang diberikan. Pada fase ini dapat dilihat tingkat kemampuan berpikir kreatif mereka melalui pendapat yang disampaikan.

Pada fase evaluasi dan pemilihan, guru mengarahkan masing-masing kelompok untuk memilih strategi pemecahan masalah yang telah mereka sampaikan pada fase sebelumnya. Keaktifan siswa terlihat saat mereka berdiskusi dengan anggota kelompoknya dalam menentukan strategi yang akan mereka pilih. Setiap kelompok sangat bersemangat dalam memilih strategi yang mereka inginkan. Terlihat siswa di masing-masing kelompok saling mengungkapkan pendapat mereka terkait strategi yang mereka pilih. Pemilihan strategi ini akan mendukung fase yang terakhir yaitu implementasi.

Pada fase implementasi, siswa menerapkan strategi yang telah mereka pilih sebagai strategi pemecahan masalah yang diberikan. Masalah yang diberikan harus diselesaikan sampai menemukan hasil akhirnya. Dalam menyelesaikan masalah, media pembelajaran sangat membantu siswa jika mereka kebingungan dalam memecahkan masalah tersebut. Pada fase ini, media pembelajaran membantu siswa dalam memahami konsep yang berkaitan dengan permasalahan. Setelah siswa menyelesaikannya, perwakilan kelompok akan menyampaikan hasil diskusi mereka di depan kelas. Saat kelompok pertama menyampaikan pendapat, terdapat kelompok lain yang bertanya karena tidak paham dan ada pula yang memberikan pendapat yang berbeda. Semangat mereka dalam mengikuti pembelajaran menunjukkan bahwa mereka memahami masalah yang diberikan.

Dari penjelasan-penjelasan di atas, hal yang berbeda terjadi pada kelas kontrol. Pada kelas kontrol, guru memberikan motivasi kepada siswa agar mereka lebih semangat dalam mengikuti pembelajaran. Antusias siswa juga terlihat dengan jelas ketika guru memulai pembelajaran. 
Tahapan pembelajaran berikutnya adalah orientasi peserta didik pada masalah. Pada fase ini siswa diberikan penjelasan serta contoh soal dan penyelesaian yang berkaitan dengan materi yang diberikan. Pada kegiatan ini, terdapat beberapa siswa yang cenderung tidak menghiraukan penjelasan guru. Kemudian pada saat guru memberikan contoh soal dan penyelesaiannya seluruh siswa menyimak dengan baik. Situasi ini tentunya mampu membuat seluruh siswa menyelesaikan soal sejenis dengan penyelesaian sejenis. Namun di sisi lain, siswa tidak menemukan cara-cara yang beragam dalam menyelesaikan soal tersebut.

Selanjutnya tahapan pembelajaran yang dilakukan adalah mengorganisasikan peserta didik. Pada tahap ini, guru membentuk siswa menjadi beberapa kelompok. Guru juga menjelaskan kepada semua kelompok terkait prosedur pengerjaan LKS. Tahap ini hampir sama dengan tahap klarifikasi masalah. Namun yang membedakan adalah proses penyelesaian masalah. Pada kelas eksperimen siswa menyampaikan gagasannya terkait strategi yang akan digunakan, namun pada kelas kontrol siswa langsung mengerjakannya.

Berikutnya adalah tahapan mengembangkan dan menyajikan hasil karya. Pada tahap ini siswa menyampaikan hasil diskusi mereka. Tahap ini hampir sama dengan tahap terakhir pada kelompok eksperimen. Persamaannya yakni siswa menyampaikan hasil diskusi di depan kelas dan kelompok lain menanggapi. Perbedaannya dengan kelas eksperimen yaitu siswa hanya menuliskan hasil diskusi mereka dan tidak menyampaikan strategi-strategi yang akan digunakan. Pada kelas kontrol hanya terpatok pada satu cara yaitu cara yang telah dicontohkan oleh guru.

Sebagai penutup kegiatan pembelajaran, guru menganalisis dan mengevaluasi proses pemecahan masalah. Pada tahapan ini sebelum siswa menyimpulkan secara umum., siswa diminta untuk mengerjakan soal yang ada di uji kompetensi pada buku paket. Setelah siswa dirasa mampu mengerjakan soal yang diberikan, selanjutnya salah seorang siswa diberikan kesempatan untuk menyampaikan kesimpulan secara umum terkait materi yang telah dipelajari pada pertemuan tersebut.

Pembelajaran yang diberikan pada kelas eksperimen dan kelas kontrol memiliki kendala masing-masing. Pada kelas eksperimen kendala-kendala yang dialami selama proses pembelajaran berlangsung adalah kebingungan siswa dalam penerapan model pembelajaran CPS dan penggunaan media pembelajaran karena baru pertama kali diterapkan di kelas serta waktu yang dibutuhkan cukup lama dalam penyampaian strategi pemecahan masalah. Meskipun terdapat beberapa kendala saat pembelajaran pada kelas eksperimen, semua kendala tersebut dapat diatasi dengan melakukan upaya yang lebih maksimal lagi untuk membuat siswa paham dengan penerapan model pembelajaran CPS berbantuan media berbasis TIK ini.

Di sisi lain model pembelajaran CPS berbantuan media berbasis TIK ini memiliki kontribusi yang begitu besar dalam menuntun siswa untuk berpikir lebih kreatif serta dengan adanya bantuan media pembelajaran sangat membantu siswa dalam memahami konsep yang diberikan, sehingga siswa lebih mudah dalam menyelesaikan masalah yang diberikan. Secara umum, dapat dinyatakan bahwa model pembelajaran CPS berbantuan media berbasis TIK mampu berjalan baik sesuai dengan harapan dan rencana. Hasil analisis juga menunjukkan hasil yang diharapkan. Adanya proses penyampaian strategi dalam penerapan model pembelajaran CPS berbantuan media berbasis TIK mampu melatih siswa untuk dapat menyelesaikan masalah dengan beragai strategi dan menggunakan strategi yang ditemukan sendiri.

Dalam penerapan pembelajaran konvensional terlihat rendahnya kontribusi penerapan model ini dalam melatih siswa untuk berpikir kreatif. Karena model ini sudah sangat dekat dengan siswa, dalam menerapkannya tidak ada kendala yang dirasa berarti. Dalam hal mengarahkan siswa untuk mampu menjawab soal-soal terkait dengan peningkatan kemampuan berpikir kreatif, model ini cenderung tidak memberikan banyak kontribusi. 
Tabel 1. RancanganPenelitian

\begin{tabular}{lcc}
\hline Kelompok & Perlakuan & Post test \\
\hline Eksperimen & $X_{1}$ & $Y$ \\
Kontrol & - & $Y$ \\
\hline
\end{tabular}

(SuharsimiArikunto, 2006)

Keterangan:

$X_{1}=$ Perlakuanberupapenerapan model pembelajaranCPSberbantuan media berbasis TIK

$Y=$ post-test

Secara umum dapat diberikan kesimpulan bahwa model pembelajaran CPS berbantuan media berbasis TIK lebih baik digunakan untuk meningkatkan kemampuan berpikir kreatif siswa dibandingkan dengan pembelajaran konvensional. Terlepas dari kendala-kendala yang dimiliki masing-masing model pembelajaran di atas, penerapan model pembelajaran CPS berhasil meningkatkan kemampuan berpikir kreatif siswa. Keberhasilan tersebut telah ditunjukkan berdasarkan uji hipotesis yang dilakukan.

\section{SIMPULAN DAN SARAN}

Berdasarkan rumusan masalah, tujuan, hasil analisis, dan pembahasan yang telah diuraikan di depan, dapat disimpulkan bahwa kemampuan berpikir kreatif dalam memecahkan masalah matematika siswa kelas VIII SMP Negeri 1 Bangli yang dibelajarkan dengan model pembelajaran CPS berbantuan media berbasis TIK lebih baik daripada kemampuan berpikir kreatif dalam memecahkan masalah matematika siswa yang dibelajarkan dengan model pembelajaran konvensional.

Berdasarkan hasil penelitian yang telah dilakukan, peneliti melalui tulisan ini menyampaikan beberapa saran sebagai berikut.

1. Kepada praktisi pendidikan, khususnya pihak-pihak yang terlibat dalam pembelajaran matematika disarankan untuk menggunakan model pembelajaran CPS berbantuan media berbasis TIK sebagai salah satu alternative pembelajaran di kelas.

2. Penelitian ini dilakukan pada sampel dan materi pembelajaran yang terbatas. Para peneliti lain yang tertarik disarankan untuk melakukan penelitian terhadap model pembelajaran CPS berbantuan media berbasis TIK dengan sampel yang lebih besar dan materi pembelajaran yang lebih luas untuk mengetahui pengaruh penerapan model pembelajaran ini dalam pembelajaran matematika secara lebih mendalam.

Salah satu cara untuk mencari koefisien validitas alat evaluasi yang berbentuk uraian adalah dengan menggunakan koefisien korelasi product-moment dari Carl Pearson (Candiasa, 2010b). Berdasarkan hasil analisis validitas tes uji coba diperoleh 4 butir soal valid. Selanjutnya, butir soal yang valid diuji reliabilitasnya. Untuk menentukan reliabilitas instrumen bentuk essay (uraian) dapat menggunakan rumus Alpha Cronbach (Candiasa, 2010a).

Berdasarkan hasil analisis reliabilitas tes, diperoleh koefisien reliabilitasnya adalah 0,711. Hasil tersebut menunjukkan bahwa tes uji coba kemampuan berpikir kreatif siswa reliabel dengan reliabilitas tinggi, sehingga soal-soal tersebut layak untuk digunakan. Keempat soal yang valid dan reliabel tersebut digunakan sebagai tes kemampuan berpikir kreatif siswa, sebab keempat soal tersebut sudah mencakup keseluruhan materi yang diajarkan.

Data kemampuan berpikir kreatif yang telah diperoleh perlu diuji dengan uji prasyarat yaitu uji normalitas dan uji homogenitas. Setelah semua uji prasyarat tersebut terpenuhi 
selanjutnya dilakukan uji hipotesis untuk memperoleh kesimpulan dari penelitian yang telah dilakukan dengan menggunakan uji-t satu ekor.

\section{DAFTAR PUSTAKA}

Ahmad S. 2011. Psikologi Sosial. Jakarta: Rineka Cipta.

Arikunto, S. 2006. Prosedur Penelitian Suatu Pendekatan Praktik. Jakarta: Rineka Cipta.

Arikunto, S. 2010. Prosedur Penelitian Suatu Pendekatan Praktik. Jakarta: Rineka Cipta

Arikunto, S. 2012. Dasar-Dasar Evaluasi Pendidikan. Jakarta: Bumi Aksara.

Aris S. 2014. 68 Model Pembelajaran Inovatif dalam Kurikulum 2013. Yogyakarta: Ar-Ruzz Media.

Arsyad A. 2016. Media Pembelajaran. Jakarta: Raja Grafindo Persada.

Azhari. 2013. Peningkatan Kemampuan Berpikir Kreatif Matematik Siswa melalui Pendekatan Konstruktivisme di Kelas VII Sekolah Menengah Pertama (SMP) Negeri 2 Banyuasin III. Jurnal Pendidikan Matematika Volume 7 No. 2 Juli 2013

Candiasa, I Made. 2010a. Pengujian Instrumen Penelitian Disertai Aplikasi ITEMAN dan BIGSTEPS. Singaraja: Universitas Pendidikan Ganesha.

Candiasa, I Made, 2010b. Statistik Univariat dan Bivariat Disertai Aplikasi SPSS. Singaraja: Universitas Pendidikan Ganesha.

Isrok'atun, Amelia Rosmala. 2018. Model-model Pembelajaran Matematika. Jakarta: PT Bumi Aksara.

Mullis, Ina V, et al. 2012. TIMSS 2011 Internasional Result in Mathematics (Trends in International Mathematics and Science Study at the Fourth and Eight Grades). Chestnut Hill,MA: TIMSS \& PIRLS International Study Center, Boston College.

Munandar, S.C. Utami. 1999. Mengembangkan Bakat dan Kreativitas Anak Sekolah. Jakarta: PT Gramedia Widiasarana Indonesia.

Sugiyono. 2012. Metode Penelitian Pendidikan. Bandung : Alfabeta. 